Martins, Ana Maria \& João Costa (2016). Ordem dos constituintes frásicos: sujeitos invertidos, objetos antepostos. In: Ana Maria Martins \& Ernestina Carrilho (eds.), Manual de Linguística Portuguesa. Berlin/Boston: De Gruyter. $371-400$.

\title{
14 Ordem dos constituintes frásicos: sujeitos invertidos; objetos antepostos
}

\begin{abstract}
Partindo da constatação de que o português é uma língua de ordem básica SVO (i.e. Sujeito-Verbo-Objeto), ${ }^{1}$ identificam-se neste capítulo diferentes fatores sintáticos, semânticos e pragmático-discursivos que motivam a alteração da ordem básica nas frases declarativas. Considerando primeiro os casos de inversão do sujeito, distinguem-se três tipos de estruturas frásicas: as frases com ordem VSO que correspondem à expressão de juízos téticos e apresentam destopicalização do sujeito; as frases com ordem VOS em que o sujeito em posição final é o foco informacional da frase (ou tem proeminência focal numa frase de foco largo); as frases com ordem VSO em que o sujeito é simultaneamente um foco contrastivo e informacional. Quanto à anteposição do objeto, o capítulo centra-se na clarificação da distinção entre estruturas de topicalização (OSV/OVS) e de focalização contrastiva (OVS), identificando propriedades gramaticais caracterizadoras de cada uma das construções por oposição à outra.
\end{abstract}

Keywords: inversão do sujeito, teticidade, foco informacional, topicalização, focalização contrastiva

\section{Introdução}

Tal como a generalidade das línguas românicas contemporâneas, o português é uma língua de ordem básica SVO, ou seja, normalmente o sujeito (S) precede o predicado e este é encabeçado pelo verbo (V), seguindo-se-lhe o complemento ou complementos verbais (O), sempre que o verbo não é monoargumental. A ordem básica dos constituintes frásicos (também dita canónica, regular ou não marcada) é a que ocorre com mais frequência em frases declarativas simples e, em geral, é sentida pelos falantes como natural em frases descontextualizadas, dependendo menos que outras ordens dos constituintes frásicos de contextos pragmático-discursivos ou fatores lexicais e morfossintáticos particulares. Também não resulta da expressão de atitudes emotivas do falante que criem um nível interpretativo adicional relativamente ao conteúdo denotativo básico da frase, como acontece nas exclamativas.

\footnotetext{
${ }^{1}$ Usa-se aqui o termo objeto (O) no sentido amplo de Larson (1988; 1990), cobrindo também o que para outros autores seriam modificadores adjuntos ao sintagma verbal e não complementos verbais stricto sensu. Por isso, o constituinte frásico que aqui identificamos como «O» corresponde a «X» para outros autores (cf., por exemplo, Leonetti 2014).
} 
Martins, Ana Maria \& João Costa (2016). Ordem dos constituintes frásicos: sujeitos invertidos, objetos antepostos. In: Ana Maria Martins \& Ernestina Carrilho (eds.), Manual de Linguística Portuguesa. Berlin/Boston: De Gruyter. 371-400.

Embora a ordem básica do português seja SVO, todas as linearizações dos elementos $\mathrm{S}, \mathrm{V}$ e $\mathrm{O}$ são possíveis, mesmo em frases descontextualizadas, como se mostra em (1a-f).

(1) a. Esse tipo de notícias pouco interessa ao cidadão comum. SVO

b. Ao cidadão comum pouco interessa esse tipo de notícias. OVS

c. Pouco interessa ao cidadão comum esse tipo de notícias. VOS

d. Pouco interessa esse tipo de notícias ao cidadão comum. VSO

e. Ao cidadão comum, esse tipo de notícias pouco interessa. OSV

f. Esse tipo de notícias, ao cidadão comum pouco interessa. SOV

A variação sintática exemplificada em (1) não significa, no entanto, que a ordem dos constituintes frásicos seja livre em português. Por um lado, as alterações da posição dos constituintes frásicos ensaiadas em (1a-f) não produzem generalizadamente, a partir de qualquer frase, resultados gramaticais. Por outro lado, as frases (1a) a (1f) só superficialmente são equivalentes. Destas duas questões (restrições e efeitos da variação na ordem dos constituintes frásicos) nos ocuparemos neste capítulo, selecionando alguns aspetos centrais do tema relativamente à gramática do português europeu.

No exemplo (1), o facto de o objeto ser um complemento preposicional (concretamente, um objeto indireto), e não nominal, é um fator favorecedor da flexibilidade da ordem dos constituintes frásicos, mas é-o também a presença do quantificador adverbial pouco como modificador do verbo. Se compararmos as frases em (1a-e) com as frases $(2 \mathrm{a}-\mathrm{e})$, que apresentam igualmente um complemento preposicional (agora locativo), verificamos que a ordem OSV deixa de ser possível, como mostra a agramaticalidade de (2e). A razão para este contraste decorre de em (1e), mas não em (2e), termos uma estrutura pragmática e informacionalmente adequada no que diz respeito à articulação entre tópico (i.e. ao cidadão comum, esse tipo de notícias) e comentário (i.e. pouco interessa). Em ambas as frases, (1e) e (2e), o objeto topicalizado e o sujeito correspondem conjuntamente ao «tópico», que equivale ao Sujeito da Predicação, no sentido lógico destes termos. Em (1e) a presença do modificador pouco torna o comentário expresso pelo Predicado pouco interessa suficientemente relevante do ponto de vista informacional. $\mathrm{O}$ mesmo não acontece em (2e) onde o Predicado estarão é despojado de conteúdo semântico e relevância informacional. Que é esta inadequação pragmática e semântica da frase (2e) que a torna inaceitável pode confirmar-se pelo contraste com a frase (3). O enriquecimento do Predicado através da adição do modificador como peixe na água torna a frase 
Martins, Ana Maria \& João Costa (2016). Ordem dos constituintes frásicos: sujeitos invertidos, objetos antepostos. In: Ana Maria Martins \& Ernestina Carrilho (eds.), Manual de Linguística Portuguesa. Berlin/Boston: De Gruyter. $371-400$

perfeitamente aceitável e natural. Este é só um exemplo de como nem todas as frases permitem todas as ordens dos constituintes frásicos e de como a sintaxe da ordem é condicionada por fatores não limitados à sintaxe.

(2) a. Parlamentares como Mariana Mortágua, do BE, ou João Galamba, do PS, estarão na Comissão Parlamentar de Inquérito. [SVO]

b. Na Comissão Parlamentar de Inquérito estarão parlamentares como Mariana Mortágua, do BE, ou João Galamba, do PS. [OVS]

c. Estarão na Comissão Parlamentar de Inquérito parlamentares como Mariana Mortágua, do BE, ou João Galamba, do PS. [VOS]

d. Estarão parlamentares como Mariana Mortágua, do BE, ou João Galamba, do PS, na Comissão Parlamentar de Inquérito. [VSO]

e. *?Na Comissão Parlamentar de Inquérito, parlamentares como Mariana Mortágua, do BE, ou João Galamba, do PS, estarão. [OSV]

(3) Na Comissão Parlamentar de Inquérito, parlamentares como Mariana Mortágua, do BE, ou João Galamba, do PS, estarão como peixe na água.

Não é objetivo deste capítulo descrever globalmente os múltiplos fatores que estão por detrás da variação na ordem dos constituintes frásicos. O capítulo centra-se nas frases declarativas, excluindo outros tipos de frases. Ficam portanto fora deste capítulo as interrogativas e exclamativas QU- que envolvem inversão do sujeito (Como conseguiu o João o passaporte?/O que não faz um dono pelo seu cão!; cf. Ambar 1992; Ambar/Veloso 2001; Barbosa 2001; Kato/Martins 2016), as exclamativas avaliativas que envolvem anteposição do objeto (Muita cerveja bebeu o João!/Muita cerveja o João bebeu!; cf. Raposo 1995; 2000; Ambar 1999; Costa/Martins 2011), e as exclamativas sem expressão de grau que derivam a ordem VSO (Dizes tu que eu vivo em Marte! (Vê lá se não acertei em tudo.)/Quer ele ser escritor! (E escreve desta maneira.)/Trabalhou o miúdo tanto e o professor dá-lhe esta nota!; cf. Barbosa 2006, 385, 112a; Martins 2013a). Feito este recorte do objeto de estudo, a secção 2 do presente capítulo será dedicada à inversão do sujeito (ordens VSO/VOS) e a secção 3 à anteposição do objeto (ordens OVS/OSV). Na secção 4 apresenta-se uma breve síntese do capítulo.

Na secção 2, sobre a inversão do sujeito nas frases declarativas, identificam-se três tipos de motivação para a inversão nas frases declarativas: 2.1 a expressão de juízos téticos (por oposição a juízos categóricos) através de frases sem a estrutura própria das predicações (i.e. Sujeito-Predicado), o que implica que o sujeito não ocupe a posição inicial de que decorreria a sua interpretação como tópico da frase; 2.2 a marcação do sujeito como foco informacional, quer seja um foco estreito, quer seja o constituinte 
Martins, Ana Maria \& João Costa (2016). Ordem dos constituintes frásicos: sujeitos invertidos, objetos antepostos. In: Ana Maria Martins \& Ernestina Carrilho (eds.), Manual de Linguística Portuguesa. Berlin/Boston: De Gruyter. 371-400.

informacionalmente proeminente numa frase de foco informacional largo; 2.3 a focalização simultaneamente informacional e contrastiva do sujeito. Enquanto a marcação do sujeito como foco informacional determina a sua colocação no final da frase, originando a ordem VOS (secção 2.2), os outros tipos de inversão do sujeito (secções 2.1,2.3) correspondem à ordem VSO.

Na secção 3, a discussão centra-se na identificação das propriedades gramaticais que caracterizam e diferenciam entre si as estruturas de topicalização (OSV/OVS) e as estruturas de focalização contrastiva (OVS) do objeto. Na esfera das línguas românicas, a construção de topicalização (cf. Duarte 1987) é uma especificidade do português que tem paralelo em línguas como o inglês (cf. Lasnik/Saito 1992). A sua inexistência em línguas românicas muito estudadas, como o espanhol e o italiano, motivou não raras confusões na literatura entre os termos topicalization e focalization, que importa dilucidar (cf. Torrego 1984, 110; Cinque 1990, 180; Rizzi 1997, 285-286), ao mesmo tempo que se clarifica a descrição da pouco estudada construção de focalização contrastiva do português europeu (cf. Costa/Martins 2011).

\section{Sujeitos invertidos}

O termo «sujeito invertido» (ou «inversão do sujeito») faz referência à substituição da posição pré-verbal do sujeito, tida por posição canónica numa língua SVO, pela posição pós-verbal. Os sujeitos invertidos de frases com predicados transitivos correspondem a dois tipos de ordem dos constituintes frásicos: a ordem VSO, como exemplificado em (4a) e (5a), e a ordem VOS, como exemplificado em (4b) e (5b). As frases VSO, como (4a) e (5a), exprimem juízos téticos, no sentido de Kuroda (1972; 1992; 2005). Nestas frases «descritivas», que serão o objeto da secção 2.1, não se põe em destaque nenhuma das entidades que são parte da situação descrita (por isso o sujeito é afastado da posição de tópico). As frases VOS, por seu lado, apresentam o sujeito em posição final como estratégia para atribuir a este constituinte proeminência prosódica e informacional. Estes casos de saliência focal do sujeito serão tratados na secção 2.2.

(4) a. Entrou um gato no jardim. (Não deixes sair o Rex.) VSO

b. Entrou no jardim o gato cinzento que o Rex odeia. (Não o deixes sair.) VOS

(5) a. Pousaram dois rabirruivos na ameixeira. (Vou tentar fotografá-los.) VSO

b. Pousou na ameixeira um pássaro lindo. (Anda cá ver. Não sei o que é.) VOS 
Martins, Ana Maria \& João Costa (2016). Ordem dos constituintes frásicos: sujeitos invertidos, objetos antepostos. In: Ana Maria Martins \& Ernestina Carrilho (eds.), Manual de Linguística Portuguesa. Berlin/Boston: De Gruyter. $371-400$

Embora em (4a) o sujeito indefinido (um gato) torne a frase particularmente natural, seria igualmente possível um sujeito definido (Entrou o gato cinzento no jardim). Por outro lado, o sujeito em posição de foco informacional nas frases VOS não tem de ser sintaticamente mais complexo do que o sujeito das frases VSO, ainda que a comparação entres as frases (a) e as frases (b) de (4) e (5) o possa sugerir. Comprova-o o par de frases em (6). Nestes exemplos, a proeminência informacional sobre o sujeito em (6b), mas não em (6a), transmite uma diferença de atitude do falante. A ordem VOS sugere surpresa relativamente à presença de uma coruja no jardim (em cuja ameixeira pousou), enquanto a ordem VSO é compatível com uma situação de familiaridade com a presença de corujas no jardim.

(6) a. Pousou uma coruja na ameixeira. / Está uma coruja pousada na ameixeira.

b. Pousou na ameixeira uma coruja. / Está pousada na ameixeira uma coruja.

O terceiro tipo de inversão do sujeito será abordado, de forma mais breve, na secção 2.3, onde se mostrará que a ordem VSO pode marcar o sujeito como foco simultaneamente contrastivo e informacional (Fiz eu tudo = 'Fui eu quem fez tudo'; Comeu ele as gomas = 'Foi ele que comeu as gomas').

\subsection{Ordem VSO como expressão gramatical da teticidade (ingl. theticity)}

As línguas naturais têm diferentes formas de expressar gramaticalmente a distinção entre juízos categóricos e juízos téticos (cf. Kuroda 1972; 1992; 2005; Sasse 1987; 1995; 1996; 2006; Lambrecht 1988; 1994; 2000; Matras/Sasse 1995). Uma das estratégias usadas por diferentes línguas românicas para sinalizar a referida distinção é a alternância entre as posições pré-verbal e pós-verbal do sujeito (cf. Duarte 1987; 1997; 2013; Martins 1994, 385-429; 2010; Leonetti 2014; Lobo/Martins no prelo-a). Nas línguas em que esta estratégia é observável, as frases que expressam juízos categóricos (referidas na literatura como frases categóricas, predicacionais ou topicalizadas) apresentam a ordem SV, sendo o sujeito interpretado como tópico (especificamente, aboutness topic, usando o termo inglês), ou seja Sujeito de uma estrutura de Predicação (no sentido da lógica aristotélica). Por sua vez, as frases que expressam juízos téticos (chamadas frases téticas, descritivas, apresentativas, não predicacionais ou não topicalizadas) podem apresentar a ordem VS, assim indicando que a frase não se estrutura através da articulação Sujeito-Predicado, própria das predicações. A inversão 
Martins, Ana Maria \& João Costa (2016). Ordem dos constituintes frásicos: sujeitos invertidos, objetos antepostos. In: Ana Maria Martins \& Ernestina Carrilho (eds.), Manual de Linguística Portuguesa. Berlin/Boston: De Gruyter. $371-400$

do sujeito funciona assim, neste caso, como forma de bloquear a sua interpretação como tópico da frase (i.e. aboutness topic) e permitir descrever uma situação sem pôr em evidência qualquer das entidades que nela participam.

«The function of a non-topicalized sentence is characterized as a description of a situation. A description affirms the cognitive presence of a conceptually or perceptually given situation. (Description) in this sense is meant to be a type of judgment. In order to better keep this in mind, it might be advisable to extend the use of the term thetic judgment and use it as a synonym of this sense of description» (Kuroda 2005, 37-38).

«A thetic judgment is a representation of a perceptually apprehended real, recalled, or imagined situation. A thetic judgment is thus by its nature dependent on another form of cognitive act, the perception of a real or imagined situation. By making a thetic judgment, one commits oneself to the truth of a proposition by describing a perceived situation, real or imagined» (Kuroda 2005, 29-30).

Na sequência textual em (7), que corresponde à descrição de uma fotografia, ${ }^{2}$ estão marcados em itálico os sujeitos pré-verbais de frases que expressam juízos categóricos. O contexto textual torna clara a sua natureza de aboutness topics (i.e. sujeitos lógicos de predicações). A frase inicial, no entanto, embora apresente também um sujeito préverbal parece dever ser interpretada como expressão de um juízo tético, correspondendo à intenção de descrever uma cena/imagem à qual pertence um homem e não de dizer alguma coisa acerca do homem que está à janela. Portanto, embora a interpretação preferencial da ordem SV, em frases descontextualizadas, seja a interpretação predicacional/categórica, a mesma ordem não impede uma interpretação descritiva/tética. Só a ordem VS é não ambígua relativamente à distinção relevante (distinção que é semântica para Kuroda 2005, mas caracterizada como informacional por outros autores, como, por exemplo, Lambrecht 2000 ou Leonetti 2014).

(7) Um homem descansa o corpo junto a uma janela. Cigarro na boca, barba de vários dias, os olhos a espelharem um cansaço sem nome, sem data, sem fim. Há uma tristeza inominável a ensombrar aquele quadro tão igual, tão decalcado das mais poderosas cenas de um qualquer filme neorrealista italiano. Com uma diferença crucial: aquele homem não é uma personagem inventada para ilustrar uma história. Aquela janela não integra um cenário imaginário apostado em proporcionar tons de realidade a uma ficção. Aquele olhar não obedece a nenhum guião apostado em suscitar veracidade à narrativa ficcionada. Aquele quadro não é um quadro. (Expresso Diário online, 30.01.2016, Valdemar Cruz)

\footnotetext{
${ }^{2}$ Trata-se de uma fotografia do fotojornalista Rui Oliveira, pertencente à exposição «Aleixo» (GaleriaAtelier Geraldes da Silva, Porto), comentada pelo jornalista Valdemar Cruz. "Aleixo» é o nome de um bairro do Porto.
} 
Martins, Ana Maria \& João Costa (2016). Ordem dos constituintes frásicos: sujeitos invertidos, objetos antepostos. In: Ana Maria Martins \& Ernestina Carrilho (eds.), Manual de Linguística Portuguesa. Berlin/Boston: De Gruyter. $371-400$.

Comentaremos a seguir exemplos de frases VSO e VS (com predicados monoargumentais) em que a inversão do sujeito é usada como recurso gramatical para a expressão da teticidade (ingl. theticity). A noção de «evidencialidade» (entendida como a fonte da evidência para uma asserção; cf. Aikhenvald 2004; De Haan 2005; Peterson/Sauerland 2010) é relevante para compreendermos alguns dos dados que serão apresentados. De facto, a descrição de situações percecionadas pelo falante, visualmente ou não (o tipo particular de evidencialidade designado por (non-)visual sensory evidentiality), envolve o tipo de ato cognitivo que subjaz aos juízos téticos e à produção das frases não topicalizadas (i.e. com ordem VS) que os expressam gramaticalmente (cf., acima, a citação de Kuroda 2005)

A frase em (8) apresenta inversão do sujeito. Nesta frase coexistem vários ingredientes que favorecem a ocorrência da ordem VSO, entre eles: o verbo estar, como nos exemplos em (9), o imperfeito do indicativo e a oração temporal introduzida por quando, como nos exemplos em (10) (cf. Barbosa 2006, 385, 112b; Martins 2010; Leonetti 2015). Estes elementos podem funcionar como marcadores de evidencialidade direta, articulando-se assim facilmente com a ordem VSO para descrever situações observadas pelo falante sensorialmente (sobretudo visualmente). Na ficção narrativa (exemplo (10a)) ou na narrativa jornalística (exemplo (8)), a ordem VSO cria um efeito sugestivo de evidencialidade sensorial.

(8) Estava a primeira-dama francesa a fazer furor em Espanha quando o passado rebelde a voltou a assombrar (Flash, 12.05.2009)

(9) a. Está um alarme a tocar há horas.

b. Está um bébé a chorar.

c. Estão uns sapatos teus no quarto do Pedrinho.

d. A: Vou fazer a barba.

B: Está o teu pai na casa de banho.

(10) a. Descia o nosso herói a Rua do Alecrim quando uma onda gigante se formou no Tejo.

b. Diz que não tem apetite, mas ontem quando cheguei a casa, comia ele um hamburger duplo e um prato de batatas fritas.

Com predicados transitivos, os complementos preposicionados facilitam enquanto os complementos nominais dificultam a ordem VSO. Imaginemos uma situação em que, estando a falar ao telefone, vemos o nosso cão ser picado por uma abelha. Uma frase possível para justificarmos a necessidade de desligar imediatamente o telefone poderá ser (11a), com ordem VSO, que, na situação descrita, é mais natural do que a ordem 
Martins, Ana Maria \& João Costa (2016). Ordem dos constituintes frásicos: sujeitos invertidos, objetos antepostos. In: Ana Maria Martins \& Ernestina Carrilho (eds.), Manual de Linguística Portuguesa. Berlin/Boston: De Gruyter. 371-400.

SVO. ${ }^{3}$ A ordem VSO deixa, no entanto, de ser uma opção se a frase for construída com o verbo picar como transitivo direto, como mostra a agramaticalidade de (11b). A cliticização do objeto permite eliminar a diferença entre a estrutura transitiva direta e indireta, passando a permitir nos dois casos a inversão do sujeito, como se vê em (12).

(11) a. (Tenho de desligar.) Picou uma abelha ao meu cão.

b. (Tenho de desligar.) *Picou uma abelha o meu cão.

(12) A: O que é que aconteceu para ele estar a ganir?

B: a. Picou-lhe uma abelha.

b. Picou-o uma abelha.

Com verbos transitivos declarativos, como dizer, contar, escrever, a ordem VSO atestase no relato jornalístico como forma de identificar a fonte da informação (apresentada como evidência indireta fidedigna), indicando ao mesmo tempo, através da inversão do sujeito, que o constituinte com a função de sujeito não é o tópico frásico e discursivo, conforme se exemplifica em (13).

(13) a. Diz o jornal «The Sun» que o inglês tinha uma álibi consistente, apoiado no depoimento de uma jovem de 15 anos, e foi logo descartado. (Expresso, 23.05.2009)

b. Escrevia o Le Monde há poucos dias, que há Boulogne - a bancada histórica, de maioria branca, sem pudor em exibir uma simpatia pela extrema-direita - e no topo oposto do estádio há Auteuil, mais heterogénea, mais recente. Entre elas, um ódio. Referem-se uns aos outros como «nazis»e «escumalha». (Público, 19.03.2010)

c. Conta a historiografia oficial que Paul Gauguin foi para Arles em Outubro de 1888, a convite do seu amigo Vincent Van Gogh, que por essa altura andava entusiasmado com a luminosidade e as cores da Provença. (Diário de Notícias, 26.05.2009)

Com predicados monoargumentais, a inversão do sujeito ocorre facilmente com verbos inacusativos, embora não esteja vedada a outros verbos intransitivos (cf. Ambar 1992; Martins 1994, 385-429; 2010; Duarte 1997; Costa 1998; 2004; Costa/Figueiredo Silva 2006; Barbosan2006; 2009; Barbosa/Duarte/Kato 2005; Kato/Martins 2016). Em frases descontextualizadas, as ordens SV e VS podem parecer indistintas nos planos semântico e pragmático-discursivo, como se exemplifica em (14).

\footnotetext{
3 A frase com ordem SVO (uma abelha picou ao meu cão) parece menos natural na situação descrita porque seria ambígua entre a expressão de um juízo tético e a expressão de um juízo categórico. Neste último caso, teríamos uma estrutura de predicação com o constituinte uma abelha posto em evidência por ser o aboutness topic da frase. Pragmaticamente, a escolha do constituinte o cão como tópico da frase seria mais adequada, originando uma frase passiva: o meu cão foi mordido por uma abelha. Curiosamente, esta frase difere da frase Piсои ита abelha ао теи са̃o em termos de evidencialidade pois não tem implícita a informação de que o falante está a descrever uma situação que acabou de presenciar.
} 
Martins, Ana Maria \& João Costa (2016). Ordem dos constituintes frásicos: sujeitos invertidos, objetos antepostos. In: Ana Maria Martins \& Ernestina Carrilho (eds.), Manual de Linguística Portuguesa. Berlin/Boston: De Gruyter. 371-400.

(14) a. Caiu um avião. / Um avião caiu.

b. O Presidente morreu. / Morreu o Presidente.

c. Os gémeos já nasceram. / Já nasceram os gémeos.

d. Um dos atletas desmaiou. / Desmaiou um dos atletas.

d. A Maria telefonou / Telefonou a Maria.

e. Já só dois moinhos funcionam. / Já só funcionam dois moinhos.

A observação de dados contextualizados torna-se necessária para perceber as diferenças relevantes, incluindo determinar se a inversão do sujeito está associada à expressão de juízos téticos ou antes à focalização do sujeito, já que nas estruturas monoargumentais a inexistência do terceiro elemento $(\mathrm{O})$ não permite, à partida, separar os dois casos.

O fragmento textual em (15) é parte de uma entrevista dada pelo escritor António Lobo Antunes à revista Visão e vem na sequência de uma conversa sobre a vivência da guerra em África pelo escritor. Neste contexto, o constituinte a guerra não é, claramente, o foco informacional da frase, nem tem qualquer tipo de proeminência focal. Por outro lado, a frase parava a guerra não é acerca do que caracterizava a guerra, antes descreve uma situação excecional (e surpreendente) observada, no contexto da guerra, por quem a relata. A ordem VS traduz assim perfeitamente a não topicalidade do sujeito frásico, ao mesmo tempo que marca a evidencialidade direta.

(15) Quando o Benfica jogava, púnhamos os altifalantes virados para a mata e, assim, não havia ataques.

Visão: Parava a guerra?

Lobo Antunes: Parava a guerra. Até o MPLA era do Benfica. (Visão, 27.11.2003)

Um traço caracterizador das frases que exprimem juízos téticos é a sua difícil compatibilidade com a negação. Como se vê nos exemplos (16) a (18), as frases afirmativas são totalmente aceitáveis quer com ordem SV quer com ordem VS mesmo que descontextualizadas (abstraindo agora dos contextos discursivos ou pragmáticos particulares em que cada uma seria mais provável ou adequada). Já nas frases negativas há um claro contraste de aceitabilidade entre as que têm ordem SV e as que apresentam inversão do sujeito. Tomadas isoladamente, as frases negativas com ordem VS são estranhas. Ao criarmos um contexto que as torne naturais, verificamos que se tornam, de forma não ambígua, casos de focalização do sujeito, como se exemplifica em (19) e (20). Se admitirmos que há uma relação forte entre teticidade e evidencialidade sensorial, podemos motivar a difícil compatibilidade entre as frases que exprimem juízos téticos e a negação (mas cf. (23c), onde uma brisa parece funcionar como um 
Martins, Ana Maria \& João Costa (2016). Ordem dos constituintes frásicos: sujeitos invertidos, objetos antepostos. In: Ana Maria Martins \& Ernestina Carrilho (eds.), Manual de Linguística Portuguesa. Berlin/Boston: De Gruyter. 371-400.

minimizador). Ou seja, tendencialmente as frases VS descrevem situações que ocorrem e são sensorialmente apreendidas.

(16) a. O Presidente morreu.

b. Morreu o Presidente.

c. O Presidente não morreu. [situação: o Presidente estava em risco de vida]

d. \#Não morreu o Presidente.

(17) a. O avião caiu.

b. Caiu o avião.

c. O avião não caiu. [situação: o avião estava em risco de queda]

d. \#Não caiu o avião.

(18) a. A Maria telefonou.

b. Telefonou a Maria.

c. A Maria não telefonou. [situação: o telefonema da Maria era esperado]

d. \#Não telefonou a Maria.

(19) Situação: sabe-se que ocorreu um acidente de viação e que há poucos sobreviventes.

A: Quem é que não morreu?

B: Não morreu [Foco o Presidente].

(20) Situação: São esperados telefonemas de várias pessoas.

A: Já telefonaram todos? / Quem é que não telefonou?

B: Não telefonou [Foco a Maria].

Com predicados que, semanticamente, envolvem direccionalidade, as frases com ordem VS traduzem obrigatoriamente contacto ou aproximação com a localização do enunciador, como mostram os exemplos (21) e (22), o que de novo remete para a relação entre teticidade e evidencialidade sensorial. Ou seja, as frases com os verbos chegar e telefonar admitem a ordem VS como expressão de juízos téticos quando o falante está diretamente envolvido na situação que descreve e a apreende visual ou auditivamente. As frases (21d) e (22-B-b) são agramaticais porque essa condição de evidencialidade direta não se verifica. Na interpretação 'chegou lá, a casa dele' (com chegar) ou 'telefonou para lá' (e não 'telefonou-me ou telefonou-nos', com telefonar) só está disponível a ordem SV, própria das frases categóricas/predicacionais. A frase (22-B-b) parece ser um pouco mais aceitável do que (21d) porque permite, um tanto marginalmente, a interpretação 'Foi a Maria que telefonou para lá e disseram-lhe que ele saía' (cf. a secção 2.3).

(21) a. O teu pai já chegou. interpretação (i): 'chegou cá, a nossa casa (ou ao lugar onde estamos)' interpretação (ii): 'chegou lá, a casa dele' 
Martins, Ana Maria \& João Costa (2016). Ordem dos constituintes frásicos: sujeitos invertidos, objetos antepostos. In: Ana Maria Martins \& Ernestina Carrilho (eds.), Manual de Linguística Portuguesa. Berlin/Boston: De Gruyter. 371-400.

b. Já chegou o teu pai. interpretação (i): 'chegou cá, a nossa casa (ou ao lugar onde estamos)' [não é possível a interpretação (ii)]

c. O teu pai já chegou a casa. Acabou de ligar a dizer que chegou bem. interpretação (ii): 'chegou lá, a casa dele'

d. *?Já chegou o teu pai a casa. Acabou de ligar a dizer que chegou bem. [agramaticalidade decorrente da impossibilidade da interpretação (ii)]

(22) A: Como é que sabes que o João sai hoje do hospital?

B: a. A Maria telefonou e disseram-lhe que ele saía. (i.e. 'telefonou para o hospital') b. ??Telefonou a Maria e disseram-lhe que ele saía.

Por fim, note-se como certos predicados monoargumentais que descrevem condições atmosféricas ou climáticas favorecem a ordem VS, chegando a torná-la obrigatória:

(23) a. Corria uma agradável brisa de fim da tarde.

b. *Uma agradável brisa de fim da tarde corria.

c. Não corre uma brisa.

d. *Uma brisa não corre.

(24) a. Sopravam ventos de $100 \mathrm{~km} / \mathrm{h}$.

b. *Ventos de $100 \mathrm{~km} / \mathrm{h}$ sopravam.

Nas frases (23b) e (24b), o verbo não tem a força semântica e informacional necessária para que a ordem SV corresponda a uma estrutura tópico-comentário aceitável. Que o problema não está no constituinte sujeito, demonstra-o a gramaticalidade das frases em (25).

(25) a. Ventos de $100 \mathrm{~km} / \mathrm{h}$ sopravam incessantemente em toda a zona costeira.

b. Uma agradável brisa de fim da tarde corria na praia, enquanto na cidade se sufocava.

\subsection{Ordem VOS e foco informacional (estreito / largo)}

Os contextos de pergunta/resposta em que a pergunta tem a forma de uma interrogativa QU- são um bom teste para determinar se a frase-resposta exibe um foco informacional largo ou um foco informacional estreito e, no segundo caso, para identificar o constituinte que, introduzindo informação nova, corresponde ao foco informacional da frase. Uma pergunta do tipo «O que aconteceu?», como em (26), determina que a fraseresposta introduza globalmente informação nova. A frase (26-B) exemplifica, portanto, um foco informacional largo. Já no par pergunta/resposta apresentado em (27) parte da informação presente na frase-resposta é pressuposta ('X não entrou no avião'); a informação nova é apenas o constituinte que, na resposta, corresponde ao pronome 
Martins, Ana Maria \& João Costa (2016). Ordem dos constituintes frásicos: sujeitos invertidos, objetos antepostos. In: Ana Maria Martins \& Ernestina Carrilho (eds.), Manual de Linguística Portuguesa. Berlin/Boston: De Gruyter. $371-400$.

interrogativo (i.e. o sintagma QU-) da pergunta. Este foco informacional estreito estabelece, assim, o valor da variável representada pelo sintagma QU- (em (27-B), Quem).

(26) A: O que aconteceu?

B: Não nos deixaram embarcar porque não tínhamos o ESTA.

(27) A: Quem é que não deixaram entrar no avião?

B: Não deixaram entrar no avião \{o professor / dois colegas / nenhum de nós\}

Como mostra (28), o sujeito ocorre na posição final da frase quando corresponde ao foco informacional estreito. A estrutura informacional motiva, portanto, a ordem VOS em vez da ordem canónica SVO, que levaria à interpretação do sujeito como tópico da frase e não como foco informacional. Por isso a frase (28B-b) não constitui uma resposta adequada à pergunta Quem é que pediu sardinhas assadas?. A sua estrutura informacional não assegura a identificação completa/exaustiva do valor da variável representada por Quem, deixando em aberto a possibilidade de outras pessoas além de «a minha mãe, a Rita e eu» terem pedido sardinhas assadas. ${ }^{4}$

(28) A: Quem é que pediu sardinhas assadas?

B: a. Pedimos sardinhas assadas [a minha mãe, a Rita e eu $]_{\text {Foco. }}$.

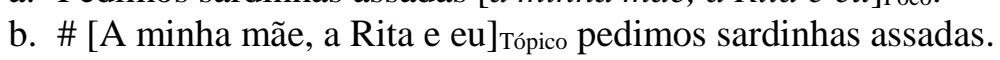

Mesmo em frases com foco informacional largo (que transmitem globalmente informação nova), a posição final da frase pode ser usada para pôr em destaque constituintes informacionalmente fortes. Deste modo associa-se a saliência prosódica, que no português recai regularmente sobre o constituinte em posição final, à

\footnotetext{
${ }^{4}$ Em contextos situacionais ou pragmáticos que tornam aceitável uma resposta não exaustiva, e só nesses, a ordem SV é possível (com o constituinte sujeito como informação nova). Assim (i-A), por exemplo, permitiria a resposta «Nós os três queremos», resposta que deixa em aberto a possibilidade de outros, além de «nós os três», também quererem.

(i) A: Quem quer uma fatia de bolo?

B: a. Queremos [Foco nós os três].

b. [Tópico Nós os três] queremos.

As respostas com elipse dos constituintes correspondentes à informação pressuposta, ou parte deles, são sempre possíveis e naturais, podendo realizar-se apenas o constituinte interpretado como foco informacional estreito, como em (ii-B-e).

(ii) A: Quem ganhou a meia maratona de Lisboa este ano?

B: a. Ganhou a meia maratona de Lisboa este ano um atleta australiano.

b. Ganhou a meia maratona de Lisboa um atleta australiano.

c. Ganhou a meia maratona um atleta australiano.

d. Ganhou um atleta australiano.

e. Um atleta australiano.
} 
Martins, Ana Maria \& João Costa (2016). Ordem dos constituintes frásicos: sujeitos invertidos, objetos antepostos. In: Ana Maria Martins \& Ernestina Carrilho (eds.), Manual de Linguística Portuguesa. Berlin/Boston: De Gruyter. $371-400$

proeminência discursiva e informacional. Um constituinte informacionalmente forte não tem de ser sintaticamente complexo e prosodicamente pesado, como demonstra o exemplo (29), no qual o sujeito em posição final é o sintagma nominal os offshores, ou o exemplo (30), outra frase de foco largo em que a ordem VOS atribui saliência focal ao sujeito nominal uma águia/orangotangos/neve.

(29) Os setores imobiliário e de hotelaria, mas também os bancos, funcionam como plataformas cada vez mais vulneráveis para ações de branqueamento de capitais. Depois entram em cena os «offshores». (Expresso, 05.01.2016, Valdemar Cruz)

(30) A: O que é que foi? O que é que estás a ver?

B: a. Não vais acreditar, mas acabou de pousar no limoeiro do quintal do prédio aqui ao lado uma águia.

b. Não vais acreditar, mas estão a aparecer de todo o lado no quintal do prédio aqui ao lado orangotangos.

c. Não vais acreditar, mas está a cair só mesmo no quintal do prédio aqui ao lado neve.

A colocação do sujeito em posição final atesta-se em frases de foco informacional largo na produção escrita contemporânea, como mostram os exemplos (31) a (39). Estes exemplos mostram também que vários fatores podem facilitar a colocação do sujeito na posição final de frases que transmitem, na sua totalidade, informação nova, embora nenhum deles seja só por si condição necessária ou suficiente. São fatores favorecedores da ordem $\mathrm{V}(\mathrm{O}) \mathrm{S}$ como estratégia de atribuição de saliência focal ao sujeito, entre outros: um sujeito sintaticamente complexo, prosodicamente pesado e informacionalmente forte; um predicado informacionalmente fraco; verbos monoargumentais; estruturas passivas; complementos verbais representados por pronomes clíticos; a presença de tópicos de localização temporal ou espacial; certas orações subordinadas, como as relativas ou as orações introduzidas por como. A mesma frase pode exibir uma combinação de vários destes fatores.

(31) Com o centro da Europa em estado de sítio, numa deriva securitária de complexos contornos, vão tornar-se inevitáveis confrontos como os de ontem em Paris, dos quais resultaram quase 300 detidos. (Expresso online, 30.11.2015, Valdemar Cruz)

(32) Nem por isso se encontram metáforas bastantes para explicar o despudor contido nas notícias sobre a facilidade de circulação de dinheiro. (Expresso online, 05.01.2016, Valdemar Cruz)

(33) Admite-se que nos inúmeros «offshores» espalhados pelo Mundo, inclusive na Madeira, circulem verbas entre os 8 e os 32 biliões de dólares da riqueza privada, ou seja, perto de metade do PIB Mundial. Sabem-no os dirigentes dos principais países. Sabem-no os 
Martins, Ana Maria \& João Costa (2016). Ordem dos constituintes frásicos: sujeitos invertidos, objetos antepostos. In: Ana Maria Martins \& Ernestina Carrilho (eds.), Manual de Linguística Portuguesa. Berlin/Boston: De Gruyter. 371-400.

responsáveis pelos principais bancos centrais. Sabem-no as principais instituições judiciais e policiais. (Expresso online, 05.01.2016, Valdemar Cruz)

(34) Vivemos, desse ponto de vista, tempos cruéis, marcados por lavandarias várias e hipocrisias sem fim. Como o revela a crise dos refugiados e o modo como vários países europeus estão a reagir a esta emergência social. Fecham-se fronteiras, como o fez ontem a Dinamarca ao fim de meio século de ligações abertas com a Suécia. Rasgam-se acordos. (Expresso online, 05.01.2016, Valdemar Cruz)

(35) Confirma-o a divulgação, ontem, dos resultados da iniciativa anualmente lançada pela Porto Editora para a escolha da palavra do ano. (Expresso online, 05.01.2016, Valdemar Cruz)

(36) Ao nível dos Estados, vão por certo prosseguir as pequenas e grandes cimeiras com sonoras e pias declarações. No terreno, persistirá a certeza de que o fluxo migratório, nem se combate com armas, nem com manifestações de intenções. (Expresso, 05.01.2016, Valdemar Cruz)

(37) Está por demonstrar a eficácia do modelo, com acumulação de debates no mesmo dia, como está por provar a bondade democrática de uma alternativa minimalista, reduzida aos frente a frente entre os nomes mais mediáticos. (Expresso online, 05.01.2016, Valdemar Cruz)

(38) Na próxima quinta-feira poderá sair da Assembleia da República uma boa notícia para quem depara com dificuldades económicas. Serão votados e aprovados, presume-se, os projetos-lei do PS, BE e PCP que impedem a penhora das casas aos cidadãos com dividas ao fisco ou à Segurança Social. (Expresso online, 05.01.2016, Valdemar Cruz)

(39) Puseram-se a jeito, é verdade. Ou colocou-os a jeito o próprio programa de arquitetura, materializado num conjunto de torres enormes, com elevados custos de manutenção e para onde foram despejadas dezenas e dezenas de famílias de fracos recursos. (Expresso online, 30.01.2016, Valdemar Cruz)

Para concluir esta secção, apresenta-se em (40) um par de frases que exemplificam a distinção entre a ordem VOS com proeminência focal sobre o sujeito e a ordem VSO como expressão da teticidade. Tanto (40a) como (40b) são frases de foco largo, não sendo portanto a esse nível que se distinguem. Mas enquanto a ordem VOS de (40a) marca o constituinte em posição final (i.e. o debate do orçamento de estado) como a informação em foco, a ordem VSO de (40b) descreve a atmosfera, cenário ou pano de fundo em que ocorre aquilo que é notícia (i.e. um deputado sentiu-se mal e desmaiou) e não recai sobre o sujeito invertido qualquer saliência prosódica ou informacional.

(40) a. Está ao rubro o debate do orçamento de estado.

b. Estava o debate do orçamento de estado ao rubro quando um deputado se sentiu mal e desmaiou. 
Martins, Ana Maria \& João Costa (2016). Ordem dos constituintes frásicos: sujeitos invertidos, objetos antepostos. In: Ana Maria Martins \& Ernestina Carrilho (eds.), Manual de Linguística Portuguesa. Berlin/Boston: De Gruyter. 371-400.

\subsection{Ordem VSO com foco contrastivo e informacional sobre o sujeito}

A alteração da ordem básica SVO pode corresponder a uma estratégia de marcação do foco informacional da frase, como vimos na secção anterior, ou a uma estratégia de marcação de um foco contrastivo, como veremos detidamente na secção 3 . Sintaticamente, focos contrastivos e focos informacionais pertencem, normalmente, a limites opostos da frase, sendo os primeiros iniciais e os segundos finais. Os focos contrastivos ou se mantêm in situ e são apenas marcados prosodicamente ou se movem para a margem esquerda da frase. $\mathrm{O}$ foco informacional, pelo contrário, pertence caracteristicamente à margem direita da frase, onde recebe um acento prosódico neutro. O contraste posicional entre um constituinte marcado como foco contrastivo e um constituinte marcado como foco informacional exemplifica-se em (41) e (42), respetivamente.

(41) A retórica é a maior arma dos políticos. Com ela se elevam, com ela se desgraçam. (Expresso, 11.09.2010, Filipe Santos Costa)

(42) A: Como é que os políticos se elevam?

B: Os políticos elevam-se com a retórica.

Do ponto de vista semântico e pragmático, os focos contrastivos introduzem um valor de oposição relativamente a uma asserção, pressuposição ou expetativa, explícita ou implicitamente presentes no domínio discursivo. A propriedade central de um foco contrastivo é a de adicionar ao valor denotativo básico da frase a expressão da atitude (discordante) do falante relativamente ao que sabe ou supõe serem as expectativas ou convicções do ouvinte. A focalização contrastiva assinala o contraste entre a informação transmitida pelo falante e a informação que, do seu ponto de vista, estaria a ser previamente assumida pelo ouvinte (Zimmermann 2007; Zimmermann/Onea 2011). O conceito de informação nova, que está na base da identificação do foco informacional, não é relevante para identificar um foco contrastivo.

O foco informacional e o foco contrastivo correspondem assim a dois planos interpretativos diferentes, pelo que os dois tipos de foco podem ser identificados na mesma frase e um mesmo constituinte pode estar associado a ambos. Relevante para o tema em discussão neste capítulo é o caso de frases com ordem VSO em que o sujeito tem um valor de foco contrastivo mas é, ao mesmo tempo, um foco informacional estreito, como no exemplo (43). Este tipo de sujeito invertido pode também pertencer a uma frase de foco largo mas ser o foco central da informação, como nos exemplos (44) 
Martins, Ana Maria \& João Costa (2016). Ordem dos constituintes frásicos: sujeitos invertidos, objetos antepostos. In: Ana Maria Martins \& Ernestina Carrilho (eds.), Manual de Linguística Portuguesa. Berlin/Boston: De Gruyter. $371-400$

a (47), este último um exemplo atestado. O facto de o sujeito ser simultaneamente marcado como foco contrastivo e foco informacional parece determinar que não ocupe nem a posição final característica do foco informacional nem a posição inicial característica do foco contrastivo anteposto. Ao mesmo tempo, o constituinte sujeito não recebe o acento prosódico contrastivo característico da marcação de foco in situ, o que confirma que a estratégia de marcação de foco seguida é sintática e opera com a possibilidade de variação na ordem dos constituintes frásicos (cf. Barbosa 2009).

(43) A: Quem põe a loiça na máquina?

B: Hoje põe $o$ João a loiça na máquina. (Não posso ser eu todos os dias!) [= 'Hoje é o João que põe a loiça na máquina.']

(44) A: Obrigada por terem feito o jantar!

B: Fiz eu tudo. (Ele não fez nada.) [= 'Fui eu que fiz tudo.']

(45) Compra $o$ João o gelado para a sobremesa? [= 'É o João que compra o gelado para a sobremesa?']

(46) Não curaste tu o Rex, curou-o o veterinário! [= 'Não foste tu que curaste o Rex, foi o veterinário.']

(47) Quando o meu herói, Ernest Shackleton, estava a 97 milhas do Pólo Sul na manhã de 9 de Janeiro de 1909 disse que dera tudo quanto tinha a dar - ora bem, hoje tenho de vos informar que dei $e u$ tudo quanto tinha a dar: Já não tenho forças para arrastar um esqui adiante do outro. (Expresso, 06.02.2016, José Cutileiro, citando Henry Worsley) [ = 'hoje tenho de vos informar que fui eu que dei tudo quanto tinha a dar']

Nas três frases retiradas de textos de imprensa que se apresentam a seguir, a ordem VSO parece ser igualmente motivada pela proeminência focal simultaneamente contrastiva e informacional do sujeito. Note-se que nas frases de (49a-b) o sujeito (destacado a itálico) poderia ser precedido de um advérbio marcador de foco como precisamente ou exatamente. Quanto à frase (48), a clivada apresentada entre parêntesis retos parece constituir uma boa paráfrase.

(48) As primárias de New Hampshire revelaram o poder dos eleitores de abanar as elites que controlam a política norte-americana, escreve $a C N N$ esta madrugada. (Expresso online, 10.02.2016, Cristina Peres)

['é a CNN que o escreve esta madrugada']

(49) a. A escritora defende que a proliferação de bancos alimentares, a falta de apoio do Estado aos serviços destinados a crianças, o ataque ao Serviço Nacional de Saúde, a comercialização do ensino nas universidades, fazem de Dickens um autor mais essencial do que nunca, dado serem muitos destes temas aqueles que o escritor defendeu e pelos quais lutou. (Expresso, 29.01.2016, Valdemar Cruz) 
Martins, Ana Maria \& João Costa (2016). Ordem dos constituintes frásicos: sujeitos invertidos, objetos antepostos. In: Ana Maria Martins \& Ernestina Carrilho (eds.), Manual de Linguística Portuguesa. Berlin/Boston: De Gruyter. 371-400.

b. É a dolorosa verdade do dia a dia daqueles a quem coube o portuense bairro social do Aleixo em sorte. (Expresso, 30.01.2016, Valdemar Cruz)

\section{Objetos antepostos: focalização vs. topicalização}

No português existem vários tipos de construções que marcam o objeto como tópico ao colocá-lo na periferia esquerda da frase. Estas construções envolvem diferentes graus de coesão sintática entre o objeto anteposto e o resto da frase, como se mostra em (50), onde se identificam também os termos usados na literatura sobre o português para designar cada uma das construções. Para uma caracterização detalhada das diferentes construções de tópicos marcados do português europeu, veja-se Duarte (1987; 2003; 2013). ${ }^{5}$

(50) a. $\{$ Livros/Quanto a livros $\}$, não posso dizer que tenho um livro preferido. (Tópico Pendente)

b. Esse segurança, eu detesto pessoas alarmistas. (Tópico Pendente)

c. [Esse segurança $]_{i}$, dá gosto conversar com [o rapaz/ele $]_{i}$. (Deslocação à Esquerda de Tópico Pendente/Deslocação à Esquerda)

d. [A esse segurança $]_{i}$, já [lhe $]_{i}$ pedi ajuda várias vezes. (Deslocação à Esquerda Clítica)

e. [A esse segurança $]_{i}$, já pedi ajuda $[-]_{\mathrm{i}}$ várias vezes. (Topicalização)

A existência da construção de topicalização, exemplificada em (50e), é uma especificidade do português ausente de outras línguas românicas, como se mostra em (51) a (53), comparando o português europeu, em (53), com o espanhol e o italiano, em (51) e (52) respetivamente. Nestas línguas, a marcação sintática de um objeto acusativo ou dativo como tópico, movendo-o para a periferia esquerda da frase, implica que esteja ligado a um pronome clítico em posição interna à frase. Ou seja, o espanhol e o italiano, como a maioria das línguas românicas, dispõem da construção de deslocação à esquerda clítica (ingl. clitic left dislocation) mas não da construção de topicalização (ingl. topicalization), enquanto o português permite ambas. Neste aspeto, o português assemelha-se ao inglês, que tem a construção de topicalização e a construção de deslocação à esquerda (sendo uma língua sem clíticos), como se exemplifica em (54). ${ }^{6}$

\footnotetext{
${ }^{5}$ Considera-se que o tópico não marcado é o sujeito das frases com ordem SVO, daí falar-se de tópico marcado quando o objeto ocupa a posição de tópico no início da frase. Na mesma frase pode existir mais do que um constituinte com função de tópico.

${ }^{6}$ Historicamente, a construção de topicalização parece ser no português uma inovação posterior ao século XVII (Martins 1994), o que explicará o contraste com as línguas da mesma família, como o espanhol e o italiano.
} 
Martins, Ana Maria \& João Costa (2016). Ordem dos constituintes frásicos: sujeitos invertidos, objetos antepostos. In: Ana Maria Martins \& Ernestina Carrilho (eds.), Manual de Linguística Portuguesa. Berlin/Boston: De Gruyter. 371-400.

(51) a. El diário, Pedro lo compró.

b. *El diário, Pedro compró. (Espanhol; cf. Zubizarreta 1999)

(52) a. Il tuo libro, lo ho comprato.

b. *Il tuo libro, ho comprato. (Italiano; cf. Rizzi 1997)

(53) a. O jornal, o Pedro comprou-o.

b. O jornal, o Pedro comprou.

c. O teu livro, já o comprei.

d. O teu livro, já comprei. (deslocação à esquerda clítica: $\sqrt{ }$ )

(topicalização: *)

(deslocação à esquerda clítica: $\sqrt{ }$ )

(topicalização: *)

(deslocação à esquerda clítica: $\sqrt{ }$ )

(topicalização: $\sqrt{ }$ )

(deslocação à esquerda clítica: $\sqrt{ }$ )

(topicalização: $\sqrt{ }$ )

(54) a. The newspaper, I have already bought it. (deslocação à esquerda: $\sqrt{ }$ )

b. The newspaper, I have already bought. (topicalização: $\sqrt{ }$ ) (Inglês; cf. Lasnik/Saito 1992)

O facto de na construção de topicalização o objeto deslocado à esquerda estar ligado a uma posição vazia no interior da frase aproxima superficialmente (no que diz respeito à ordem dos constituintes frásicos) a construção de topicalização da construção de focalização e criou bastante ruído na literatura relativamente ao uso de cada um dos termos.

Torrego $(1984,110)$ é talvez a primeira autora que, na literatura sobre as línguas românicas, chama a atenção para a confusão terminológica entre topicalization e focalization. Mas, alguns anos mais tarde, Cinque (1990) ainda usa o termo topicalization para designar a construção de focalização contrastiva:

«As mentioned in chapter 1, topicalization could more appropriately be termed Focus Movement in Italian, since its left-peripheral phrase obligatorily bears heavy stress, its pragmatic function being to contrast the stopicalized constituent with some other constituent. I nonetheless retain the term topicalization here to emphasize its syntactic identity to the English construction (though the pragmatics of the latter is indeed closer to that of CLLD [Clitic Left Dislocation] in Italian (...)). For the sake of clarity, I will continue to capitalize topicalized constituents» (Cinque 1990, 180).

É só a partir do trabalho de Rizzi (1997) que parece criar-se um consenso em torno do significado de cada um dos termos, pelo menos no domínio das línguas românicas:

«A traditional articulation of the clause that typically involves the left periphery is the articulation in topic and comment, as expressed by the English construction referred to as Topicalization [Your book, you should give t to Paul (not to Bill)] [...]. Formally similar but interpretatively very different is the focus-presupposition articulation [YOUR BOOK you should give $t$ to Paul (not mine)] [...]. In Italian and more generally in Romance, the topic-comment articulation is typically expressed by the construction that Cinque (1990) has called Clitic Left Dislocation (CLLD), involving a resumptive clitic 
Martins, Ana Maria \& João Costa (2016). Ordem dos constituintes frásicos: sujeitos invertidos, objetos antepostos. In: Ana Maria Martins \& Ernestina Carrilho (eds.), Manual de Linguística Portuguesa. Berlin/Boston: De Gruyter. 371-400.

coreferential to the topic [...]. The focus-presupposition articulation can be expressed in Italian by preposing the focal element (focalization) and assigning it special focal stress [...]. In Italian this option is restricted to contrastive focus» (Rizzi 1997, 285-286).

O tema central desta secção será a identificação das propriedades que distinguem, no português europeu, a construção de focalização contrastiva da construção de topicalização. Como a primeira tem sido menos estudada do que a segunda, os dados que serão apresentados incidem sobretudo na construção de focalização e a descrição será feita na perspetiva de caracterização desta construção, tomando a topicalização como elemento de comparação e contraste. Para uma caracterização exaustiva da construção de topicalização, veja-se Duarte (1987; 2013); sobre a distinção entre foco contrastivo e foco informacional, veja-se acima a secção 2.1.3 e Costa/Martins (2011).

\subsection{Equivalência interpretativa com estruturas clivadas}

As estruturas de focalização são interpretativamente equivalentes a estruturas clivadas, o que não acontece com as estruturas de topicalização (cf. Hernanz/Brucart 1987; Zubizarreta 1998; 1999). Aos constituintes clivados ou focalizados corresponde, em geral, uma interpretação exaustiva, que os distingue dos constituintes topicalizados.

A frase (55), com topicalização de a esse país, não encontra uma boa paráfrase numa clivada canónica, como demonstra a possível continuação mas não é o único, que indica que o objeto anteposto não tem uma interpretação exaustiva.

(55) A esse país, não tenho vontade de ir. Mas não é o único.

[₹ ‘É a esse país que não tenho vontade de ir']

Ao contrário das frases com topicalização, as frases com focalização do objeto são sempre parafraseáveis por estruturas clivadas (cf. Lobo/Martins, no prelo-b), como se exemplifica em (56) e (57). Os constituintes com ela, em (56), e de pés de veludo, em (57), têm interpretação exaustiva nas frases em que ocorrem como focos contrastivos antepostos, tal como nas frases em que são o constituinte clivado.

(56) A retórica é a maior arma dos políticos. Com ela se elevam, com ela se desgraçam. (Expresso, 11.09.2010, Filipe Santos Costa)

[= 'é com ela que se elevam e é com ela que se desgraçam']

(57) Zeca Afonso era antes de mais um poeta. Num tempo de fala curta, construía metáforas de alcance longo e falava de vampiros para evocar quem de pés de veludo chegava para sugar o sangue fresco da manada. (Expresso online, 05.01.2016, Valdemar Cruz) [= 'para evocar quem era de pés de veludo que chegava'] 
Martins, Ana Maria \& João Costa (2016). Ordem dos constituintes frásicos: sujeitos invertidos, objetos antepostos. In: Ana Maria Martins \& Ernestina Carrilho (eds.), Manual de Linguística Portuguesa. Berlin/Boston: De Gruyter. 371-400.

A proximidade interpretativa entre a focalização e as clivadas faz com que seja possível não só parafrasear uma frase com focalização por outra com uma estrutura clivada, como fazer o exercício contrário, conforme se mostra em (58) e (59). Tenha-se em atenção que a equivalência é apenas semântica, e não sintática. O exemplo (60), que tem como ponto de partida uma estrutura pseudoclivada (em vez de uma clivada canónica), mostra como a equivalência semântica se mantém mesmo quando o constituinte clivado se situa na margem direita da frase, enquanto o constituinte focalizado pertence à margem esquerda da frase.

(58) Pois é de lá que vem a mais escandalosa das notícias: o confisco dos bens dos refugiados. (Expresso online, 28.01.2016, Cecília Meireles)

[= 'Pois de lá vem a mais escandalosa das notícias'; o antecedentente do locativo lá é «a Dinamarca», um país de onde não se esperaria a mais escandalosa das notícias]

(59) É no final de «Another One», o álbum que Mac DeMarco acaba de lançar, que se encontra a chave não só da postura do canadiano, como da sua casa. (Expresso 08.08.2015, Lia Pereira)

[= 'No final de «Another One», o álbum que Mac DeMarco acaba de lançar, se encontra a chave...']

(60) O que eu transmiti aos meus jogadores foi isto: «Ou matamos ou morremos.» (Expresso, 08.08.2015, entrevista a Rui Vitória]

[= 'Isto transmiti eu aos meus jogadores: ...']

As duas frases que se seguem, ambas atestadas, constituem evidência adicional relativamente à proximidade, nos planos semântico e pragmático-discursivo (ainda que não em produtividade de uso), entre a construção de focalização e as estruturas clivadas.

(61) Não lhe respondi, e pareceu-me que aquela cena tinha sido comicamente absurda, como que representada por homens que tinham voltado à adolescência, ou, como seria o caso do Rodrigues e do Luís, não tinham saído dela ou não sairiam nunca. Isto me aproximou do meu primo. (Jorge de Sena, Sinais de Fogo, in: CRPC, \#\#\#8 Linguística de corpus e outros usos dos corpora em linguística)

[= 'foi isto que me aproximou do meu primo']

(62) Todos fazemos coisas de sucesso fácil, mas raramente pomos a fasquia acima do que julgamos estar ao nosso alcance. É isso que me motiva aqui. (Expresso, 06.02.2016, José Cutileiro, citando Henry Worsley)

\subsection{Colocação dos pronomes clíticos}

A topicalização não afeta a colocação dos pronomes clíticos. Assim, nas frases finitas, afirmativas, que não incluem elementos desencadeadores de próclise, os pronomes 
Martins, Ana Maria \& João Costa (2016). Ordem dos constituintes frásicos: sujeitos invertidos, objetos antepostos. In: Ana Maria Martins \& Ernestina Carrilho (eds.), Manual de Linguística Portuguesa. Berlin/Boston: De Gruyter. 371-400.

átonos têm a colocação enclítica que caracteriza o português europeu. Pelo contrário, a focalização torna obrigatória a colocação pré-verbal dos pronomes clíticos pois os focos contrastivos antepostos são, eles próprios, desencadeadores de próclise (\#\#\#15 A colocação dos pronomes clíticos em sincronia e diacronia; cf. Martins 2013b para uma identificação completa dos itens proclisadores no português europeu).

No exemplo (63) podemos ver o contraste entre a frase (63a), que apresenta focalização e próclise, e o exemplo (63b), que apresenta topicalização e ênclise. A possibilidade de parafrasear (63a) com uma frase clivada mostra que se trata de focalização. A frase (63b), em que o objeto anteposto está topicalizado, não tem correspondência numa clivada (seria agramatical a frase *se o livro saiu bem,é a si que se deve роисо).

(63) a. Se o livro saiu bem, a si se deve (mensagem de sms de editor para autor) [ = 'Se o livro saiu bem é a si que se deve']

b. Se o livro saiu bem, a si, deve-se pouco.

Em (64) a (66) dão-se exemplos adicionais da colocação proclítica dos pronomes átonos na construção de focalização (em frases em que não há outro proclisador senão o próprio constituinte focalizado). Entre parêntesis retos, a seguir aos exemplos (66) e (67), mostra-se que as frases se tornariam agramaticais com o pronome clítico colocado depois do verbo, o que decorre da impossibilidade de, nestes casos, obter uma estrutura de tópico-comentário bem formada (cf. secção 3.5).

(64) Justamente, meu caro amigo, por vir para as empresas da família lhe exijo muito mais do que aos outros. (CRPC, Lobo Antunes, Fado)

[= 'por vir para as empresas da família é que lhe exijo muito mais do que aos outros']

(65) O que aqui interessa é que há vontade de pôr as coisas pela positiva. Sem ponta de ironia o escrevo: todos queremos que as «instituições» melhorem. (Expresso 09.05.2015, Pedro Santos Guerreiro)

[= 'É sem ponta de ironia que o escrevo']

[*Sem ponta de ironia, escrevo-o. Cf.: Escrevo-o sem ponta de ironia.]

(66) Infelizmente, e com tristeza o digo, pela consideração que tenho por Vital Moreira, o apontamento dele não é menos abusivo do que o discurso de Paulo Rangel no Parlamento Europeu acerca da minha entrevista. (Expresso online, 05.02.2016)

[*Com tristeza, digo-o. Cf.: Digo-o com tristeza] 
Martins, Ana Maria \& João Costa (2016). Ordem dos constituintes frásicos: sujeitos invertidos, objetos antepostos. In: Ana Maria Martins \& Ernestina Carrilho (eds.), Manual de Linguística Portuguesa. Berlin/Boston: De Gruyter. $371-400$

\subsection{Anteposição de expressões não referenciais}

A topicalização é condicionada pelas propriedades referenciais das expressões nominais, não sendo topicalizáveis as palavras negativas nem os quantificadores puros (cf. Duarte 1987; 1997; Martins 1997; Barbosa 2006). As estruturas de focalização não estão sujeitas a este tipo de restrições, como mostram os exemplos (67) a (71), em que ocorrem focalizadas as palavras negativas nada, ninguém e os quantificadores pouco, tudo, poucas. As palavras negativas comportam-se, no entanto, de forma particular relativamente à inversão do sujeito (cf. secção 3.5) e a outras propriedades (cf. secção 3.8), constituindo-se num caso especial de focalização.

(67) As investigações duraram anos e no fim pouco ou nada se ficou a saber.

(68) São declarações que em nada contribuem para o bom andamento das negociações.

(69) Só a diplomacia resolveria este conflito, mas parece que a ninguém interessa esta solução. (Diário de Notícias, 06.09.2013, Maria João Tomás)

(70) Comovente foi ver as igrejas cheias com um público para quem tanto Vivaldi como Feldman são novidade e que tudo escutam... religiosamente. (Expresso, 23.07.2011, Jorge Calado)

(71) Poucas são as mulheres que precisam de um homem para as sustentar. (Expresso, 06.02.2016, Maria Filomena Mónica)

\subsection{Inversão do sujeito}

A focalização de expressões referenciais torna obrigatória a inversão do sujeito, originando a ordem OVS quando o objeto está focalizado. A topicalização, pelo contrário, não condiciona, por si, a posição do sujeito e é perfeitamente compatível com a ordem OSV, como mostram os exemplos em (72).

(72) a. A esse espetáculo, os meus amigos aconselharam-me a não ir.

b. Espinafres, o João odeia.

As frases com ordem OVS (73) a (75) exemplificam a inversão do sujeito na construção de focalização. As correspondentes frases agramaticais com ordem OSV (apresentadas entre parêntesis retos a seguir a cada exemplo) não podem ser salvas pela focalização simultânea dos dois constituintes pré-verbais porque a focalização contrastiva (diferentemente da topicalização) apenas pode marcar um constituinte por frase (cf. secção 3.8). 
Martins, Ana Maria \& João Costa (2016). Ordem dos constituintes frásicos: sujeitos invertidos, objetos antepostos. In: Ana Maria Martins \& Ernestina Carrilho (eds.), Manual de Linguística Portuguesa. Berlin/Boston: De Gruyter. 371-400.

(73) No esquecimento ficaria outra história: (...) (Expresso, 07.12.2013) [*No esquecimento outra história ficaria.]

(74) De lá vem a mais escandalosa das notícias. [*De lá a mais escandalosa das notícias vem.]

(75) A grande notícia te dou eu agora.

[*A grande notícia eu te dou agora.]

No exemplo (76), a alteração da ordem OVS para OSV é possível mas altera completamente a interpretação da frase inicial, como evidenciam as paráfrases entre parêntesis retos. A explicação para a diferença semântica entre (76a) e (76b) é que na primeira frase o objeto anteposto está focalizado, enquanto na segunda está topicalizado.

(76) a. Assim trabalho eu. (Expresso, 11.01.2016, Alexandra, citando Júlio Pomar) [= 'é assim que eu trabalho']

b. Assim, eu trabalho. [= 'assim/dessa maneira, eu aceito trabalhar']

A inversão do sujeito torna-se opcional na construção de focalização, podendo mesmo deixar de ser a opção preferencial, quando a expressão referencial focalizada está associada a um marcador de foco como só ou até, o que é exemplificado em (77).

(77) a. Só na Bélgica, Holanda e Luxemburgo é legal a eutanásia.

b. Só na Bélgica, Holanda e Luxemburgo a eutanásia é legal.

c. Até ao filho pede o cretino dinheiro emprestado.

d. Até ao filho o cretino pede dinheiro emprestado.

A inversão do sujeito também não é obrigatória quando estão focalizadas palavras negativas. Assim, em (78), podemos ver como a mesma frase admite tanto a ordem OVS como a ordem OSV. Veja-se Costa/Martins (2011) para uma explicação da opcionalidade da inversão do sujeito quando estão focalizados constituintes que integram palavras negativas ou marcadores de foco como só e até.

(78) a. Parece que a ninguém interessa essa solução.

b. Parece que a ninguém essa solução interessa. 
Martins, Ana Maria \& João Costa (2016). Ordem dos constituintes frásicos: sujeitos invertidos, objetos antepostos. In: Ana Maria Martins \& Ernestina Carrilho (eds.), Manual de Linguística Portuguesa. Berlin/Boston: De Gruyter. $371-400$

\subsection{Peso informacional do predicado verbal}

A topicalização não é permitida quando o comentário (dentro da estrutura tópicocomentário em que a construção se articula) não tem suficiente peso/relevância informacional. A focalização não apresenta este tipo de restrição como demonstra a boa formação das frases em (79) a (82), as quais não encontram correspondência possível em estruturas de topicalização. As frases apresentadas entre parêntesis retos e marcadas como agramaticais podem ser claramente identificadas como casos de topicalização porque exibem ordem OSV ou ênclise (cf. secções 3.2 e 3.4).

(79) De notícias se faz o nosso mundo. (Slogan da RTP N)

[*De notícias, o nosso mundo faz-se. Cf.: O nosso mundo faz-se de notícias.]

(80) Na crise financeira reside o problema.

[*Na crise financeira, o problema reside. Cf.: O problema reside na crise financeira.]

(81) Destas quatro partes consta o relatório.

[*Destas quatro partes, o relatório consta. Cf.: O relatório consta destas quatro partes.]

(82) Sem ponta de ironia o escrevo. (Expresso 09.05.2015, Pedro Santos Guerreiro)

[*Sem ponta de ironia, escrevo-o. Cf.: Escrevo-o sem ponta de ironia.]

Alguns autores têm considerado que é uma restrição de natureza prosódica que está por detrás da agramaticalidade das frases com topicalização em que o comentário não tem o peso necessário (cf. Frota/Vigário 1996; Duarte 2013, 420). Ou seja, para estes autores estaria em causa o peso prosódico e não o peso/relevância informacional do comentário como condição de boa formação das estruturas de topicalização. Contudo, diferenças de aceitabilidade como as exemplificadas em (83) e (84) mostram que é a relevância informacional do comentário relativamente ao tópico, e não o peso prosódico do comentário, que condiciona a aceitabilidade da topicalização. Tenha-se em atenção que as formas verbais de (83b/d) e (84b) podem ser produzidas com acento prosódico neutro (ou seja, não necessitam de um acento contrastivo para que as frases sejam bem formadas). O mesmo acontece com a forma verbal vi em (85).

(83) a. ??Esse livro, escrevi.

b. Esse livro, \{odiei / adorei $\}$.

c. ?Esse livro, lemos. (Duarte 2013, 420)

d. Esse livro, estudámos.

(84) a. *Sem ironia, escrevo-o.

b. Sem ironia, \{vegeta-se/definha-se 
Martins, Ana Maria \& João Costa (2016). Ordem dos constituintes frásicos: sujeitos invertidos, objetos antepostos. In: Ana Maria Martins \& Ernestina Carrilho (eds.), Manual de Linguística Portuguesa. Berlin/Boston: De Gruyter. $371-400$.

(85) Esse filme, vi. (O do Nanni Moretti é que não vi.)

\subsection{Relação com o quantificador flutuante todos}

Os constituintes antepostos por topicalização podem desprender-se do quantificador flutuante todos, o que não acontece com os constituintes focalizados (cf. Duarte 1997), como demonstra o contraste de gramaticalidade entre as frases (86b) e (87b). As frases (87a-b) representam a construção de topicalização, como evidencia a colocação do clítico em ênclise; as frases (88a-b) representam a construção de focalização, o que é confirmado pela colocação do clítico em próclise (cf. secção 3.2).

(86) a. Estes livros todos, ofereceu-me a Maria.

b. Estes livros, ofereceu-me a Maria todos.

(87) a. ESTES LIVROS TODOS me ofereceu a Maria.

b. *ESTES LIVROS me ofereceu a Maria todos.

\subsection{Extraposição de orações relativas}

A focalização torna possível a extraposição de orações relativas, a topicalização não (cf. Cardoso 2010, de onde são extraídos os exemplos (88) e (89)). A comparação entre os exemplos (88a) e (88b) mostra que o constituinte crianças que não gostam de chocolate pode ser topicalizado. Por sua vez, o contraste de gramaticalidade entre (88c) e (88d) demonstra que o nome crianças não pode ser movido para a posição de tópico, desligando-se do modificador relativo que não gostam de chocolate, mas pode ser movido para a posição de foco contrastivo nas mesmas circunstâncias. A quantificação por poucas desambigua a estrutura da frase (88d), tornando-a um exemplo claro de focalização (cf. secção 3.3). As frases (89) a (91) são exemplos adicionais da compatibilidade entre a construção de focalização e a extraposição de orações relativas. O contraste de gramaticalidade entre (89a) e (89b) é mais uma vez revelador de que a focalização e a topicalização interagem de forma diversa com a extraposição de orações relativas.

(88) a. Também conheço crianças que não gostam de chocolate.

b. Crianças que não gostam de chocolate, também conheço.

c. *Crianças, também conheço que não gostam de chocolate.

d. Poucas crianças conheço que não gostam de chocolate.

(89) a. Uma estranha doença lhe diagnosticaram que lhe retirou toda a alegria.

b. *Uma estranha doença, diagnosticaram-lhe (então) que lhe retirou toda a alegria. 
Martins, Ana Maria \& João Costa (2016). Ordem dos constituintes frásicos: sujeitos invertidos, objetos antepostos. In: Ana Maria Martins \& Ernestina Carrilho (eds.), Manual de Linguística Portuguesa. Berlin/Boston: De Gruyter. 371-400.

(90) Poucos colegas consultei que tenham contribuído com qualquer sugestão interessante.

(91) Parece certo que novas orientações serão dadas que tornam inútil todo o trabalho que fizemos.

\subsection{Recursividade e ordem relativa de tópicos e focos contrastivos}

Na mesma frase pode ocorrer mais do que um constituinte topicalizado. À recursividade da topicalização opõe-se a limitação da focalização a um constituinte por frase (cf. Zubizarreta 1999). A frase (92a) apresenta o constituinte em Itália na posição de tópico, mas é possível modificá-la de modo a trazer para uma segunda posição de tópico outros constituintes, como se mostra em $(92 b-c){ }^{7}$ A ocorrência de mais do que um tópico por frase não altera as propriedades da topicalização descritas nas secções anteriores. Assim, (92d), por comparação com (92b-c), mostra, por exemplo que a opcionalidade de inversão do sujeito se mantém.

(92) a. Em Itália, o assunto será discutido no Parlamento já em março. (Expresso online, 10.02.2016, Cristina Peres)

b. Em Itália, já em março, o assunto será discutido no Parlamento.

c. Em Itália, no Parlamento, o assunto será discutido já em março.

d. Em Portugal, no Parlamento, não está ainda agendada a discussão sobre a legalização da eutanásia.

Coexistindo na mesma frase dois constituintes topicalizados, a sua posição relativa pode alternar, como se exemplifica em (93). Esta propriedade, tal como a recursividade, estende-se a outras construções de tópicos marcados. Os pronomes clíticos apresentados entre parêntesis nas frases de (93) confirmam que, no aspeto em análise, a topicalização e a deslocação à esquerda clítica são semelhantes.

(93) a. Um cão, ao meu filho, dou(-lho) assim que ele me pedir.

b. Ao meu filho, um cão, dou(-lho) assim que ele me pedir.

c. Os títulos dos livros, nessa estante tão alta, não (os) consigo ler.

d. Nessa estante tão alta, os títulos dos livros, não (os) consigo ler.

e. Aos animais, no jardim zoológico, não se pode dar(-lhes) comida.

f. No jardim zoológico, aos animais, não se pode dar(-lhes) comida.

\footnotetext{
${ }^{7} \mathrm{O}$ conjunto de frases em (i) mostra a possibilidade de diferentes constituintes alternarem na posição de tópico (compare-se (ia) com (ib)) sem, no entanto, poderem ser topicalizados simultaneamente, como mostra (ic). A agramaticalidade de (ic) é consequência da condição relativa ao peso informacional do comentário que se discutiu na secção 3.4. O comentário tem de ser suficientemente relevante enquanto predicado acerca do tópico.

(i) a. Amanhã, quinta-feira, o Eurogrupo discute o plano orçamental português. (Expresso online, 10.02.2016, Cristina Peres)

b. O plano orçamental português, o Eurogrupo discute amanhã, quinta-feira.

c. *?Amanhã, quinta-feira, o plano orçamental português, o Eurogrupo discute.
} 
Martins, Ana Maria \& João Costa (2016). Ordem dos constituintes frásicos: sujeitos invertidos, objetos antepostos. In: Ana Maria Martins \& Ernestina Carrilho (eds.), Manual de Linguística Portuguesa. Berlin/Boston: De Gruyter. 371-400.

As palavras negativas constituem uma exceção à limitação dos focos contrastivos antepostos a um constituinte por frase (recorde-se que as palavras negativas não podem ser tópicos). Diferentemente das expressões referenciais, as palavras negativas tornam possível a focalização simultânea de diferentes constituintes, mais uma vez indicando serem um caso particular dentro das estruturas de focalização (cf. secções 3.3 e 3.4). Na frase (94a) coocorrem em posição pré-verbal os constituintes nunca, nada e de ninguém. As frases (94b-d) evidenciam que qualquer deles poderia ocorrer em posição pós-verbal. Diferentemente dos tópicos, as palavras negativas focalizadas parecem ter uma ordenação linear fixa.

(94) a. Nunca nada de ninguém se saberá.

b. Nunca nada se saberá de ninguém.

c. Nada de ninguém se saberá nunca.

d. Nunca de ninguém se saberá nada.

Sendo topicalização e focalização duas construções distintas, podem coocorrer na mesma frase. Neste caso, como mostram os exemplos (95) a (98), o constituinte topicalizado precede o constituinte focalizado. Note-se que nas frases (97) e (98) não há recursividade da focalização, já que cada um dos focos contrastivos antepostos pertence a uma oração diferente dentro da estrutura de coordenação.

(95) a. [Dele, $]_{\text {Tópico }}[\text { pouco ou nada }]_{\text {Foco }}$ sei.

b. [A vocês $]_{\text {Tópico }}[\mathrm{com} \text { alegria }]_{\text {Foco }} \mathrm{O}$ digo.

(96) O Muro tinha ruído, a União Soviética tinha implodido, o mundo banhava-se na luz astral do capitalismo como sistema perfeito. [Nos desertos de África e do Afeganistão,] Tópico [um admirável mundo novo] $]_{\text {Foco }}$ se preparava. (Expresso, 25.08.2012, Clara Ferreira Alves)

[= 'Nos desertos de África e do Afeganistão, era um admirável mundo novo o que se preparava']

(97) [Na Administração Pública Portuguesa, $]_{\text {Tópico }}[\text { tudo] }]_{\text {Foco }}$ se cria, [nada $]_{\text {Foco }}$ se perde e [nada] $]_{\text {Foco }}$ se transforma. (Expresso, 31.12.2015, Miguel Sousa Tavares)

(98) $[\text { Ali, }]_{\text {Tópico }}[\text { nada }]_{\text {Foco }}$ se perdeu e [nada $]_{\text {Foco }}$ se transformou. (Expresso, 31.12.2015, Miguel Sousa Tavares)

A partir da frase apresentada em (99a), com o constituinte na Europa na posição de tópico, é possível construir (99b), com focalização sintática de só na Bélgica, Holanda e Luxemburgo (em vez da focalização in situ), mas não é possível (99c). Nesta última 
Martins, Ana Maria \& João Costa (2016). Ordem dos constituintes frásicos: sujeitos invertidos, objetos antepostos. In: Ana Maria Martins \& Ernestina Carrilho (eds.), Manual de Linguística Portuguesa. Berlin/Boston: De Gruyter. $371-400$

frase, o constituinte na Europa ocorre à direita do constituinte focalizado, não sendo portanto um tópico. Também não pode ser um foco anteposto, dada a limitação destes a um constituinte por frase. Daqui decorre a agramaticalidade de (99c), tal como de (99d). $\mathrm{Na}$ frase (99e) parece ser a incompatibilidade entre a colocação no final da frase do constituinte na Europa e a sua interpretação como tópico que provoca a agramaticalidade. Curiosamente, uma estrutura clivada melhoraria a aceitabilidade da frase, enquanto a supressão do marcador de foco só a tornaria de todo inaceitável (cf. as frases dadas entre parêntesis retos). Isto mostra que muito fica por explorar relativamente à interface sintaxe-semântica das estruturas de focalização, topicalização e clivagem e ao modo como estas estruturas interagem entre si.

(99) a. Na Europa, a eutanásia só é legal na Bélgica, Holanda e Luxemburgo. (Expresso online, 10.02.2016, Cristina Peres)

b. Na Europa, só na Bélgica, Holanda e Luxemburgo é legal a eutanásia.

c. *Só na Bélgica, Holanda e Luxemburgo na Europa é legal a eutanásia.

d. *?Só na Bélgica, Holanda e Luxemburgo SEM RESTRIÇõES é legal a eutanásia.

e. ??Só na Bélgica, Holanda e Luxemburgo é legal a eutanásia na Europa. [É só na Bélgica, Holanda e Luxemburgo que é legal a eutanásia na Europa.] [*Na Bélgica, Holanda e Luxemburgo é legal a eutanásia na Europa.]

\section{Conclusão}

Descrevem-se neste capítulo ordens não canónicas dos constituintes frásicos que correspondem ou à anteposição do objeto (OSV/OVS) ou à inversão do sujeito (VSO/VOS), relativamente à ordem básica SVO. Procura-se esclarecer a que estratégias gramaticais correspondem as ordens não canónicas (marcação de tópico, marcação de foco contrastivo, marcação de foco/proeminência informacional, marcação de foco simultaneamente contrastivo e informacional, marcação de teticidade), que fatores, internos à frase ou contextuais, favorecem ou limitam cada um dos tipos de anteposição do objeto e de inversão do sujeito, que propriedades sintáticas caracterizam as diferentes estruturas com alteração da ordem básica e que efeitos interpretativos delas decorrem.

A partir da frase com ordem básica «A princesa apaixonou-se pelo ogre», as frases com anteposição do objeto, em (i)-(ii), e com inversão do sujeito, em (iii)-(vi), ilustram as principais estruturas estudadas ao longo do capítulo. 


\section{Objetos antepostos}

(i) Pelo ogre, a princesa apaixonou-se.

Tópico (topicalização)

(Mas também se apaixonou pelo príncipe.)

(ii) Pelo ogre se apaixonou a princesa. [= 'Foi pelo ogre que a princesa se apaixonou.']

Foco contrastivo (focalização)

\section{Sujeitos invertidos}

(iii) Quem se apaixonou pelo ogre?

Apaixonou-se pelo ogre a princesa.

Foco informacional (foco estreito)

(iv) Esta história conta como se apaixonou pelo ogre a princesa Branca de Neve.

Saliência informacional (foco largo)

(v) Estava a princesa apaixonada pelo ogre, quando chegou um príncipe diferente de todos os

Frase tética/descritiva (teticidade) outros.

(vi) Estás a contar mal a história. Apaixonou-se a princesa pelo ogre, não foi a rainha.

Foco contrastivo e informacional [= 'Foi a princesa quem se apaixonou pelo ogre, não foi a rainha.']

O exemplo (vi) mostra que um foco contrastivo sobre o sujeito numa frase de ordem VSO pode ser corretivo. Pelo contrário, o foco contrastivo anteposto, exemplificado em (ii), não é natural em contextos corretivos no português europeu. ${ }^{8} \mathrm{O}$ foco contrastivo associado à ordem VSO tipicamente evoca ou traz para o domínio do discurso as entidades com as quais se estabelece o contraste (i.e. compara explícita ou implicitamente alternativas particulares; cf. os exemplos da secção 2.3), por isso são muito naturais as continuações corretivas.

As diferentes opções de posicionamento do sujeito frásico podem traduzir diferenças subtis de atitude do falante sem alterar o conteúdo proposicional básico da frase, como se exemplifica em (vii)-(ix) fazendo o constituinte sujeito alternar entre a posição pré-verbal de tópico numa frase categórica, a posição imediatamente pós-verbal de uma frase tética e a posição final associada à marcação de foco informacional.

(vii) Morreram dez pessoas no acidente, 18 encontram-se em estado grave e cerca de 90 sofreram ferimentos ligeiros. (Expresso online, 10.02.2016, Cristina Peres)

(viii) Morreram dez pessoas no acidente, encontram-se 18 em estado grave e sofreram cerca de 90 ferimentos ligeiros.

(ix) Morreram dez pessoas no acidente, encontram-se em estado grave 18 e sofreram ferimentos ligeiros cerca de 90.

\footnotetext{
${ }^{8} \mathrm{O}$ português europeu parece comportar-se neste aspeto diferentemente de outras línguas românicas (cf. Rizzi 1997; Zubizarreta 1999; Bianchi/Bocci/Cruschina 2015). Note-se que o foco contrastivo anteposto pode incidir sobre o sujeito, em vez do objeto, caso em que a ordem dos constituintes frásicos será SVO mas se mantêm, genericamente, as propriedades descritas na secção 3 para a construção de focalização (cf. Lobo/Martins 2016-b).
} 
Martins, Ana Maria \& João Costa (2016). Ordem dos constituintes frásicos: sujeitos invertidos, objetos antepostos. In: Ana Maria Martins \& Ernestina Carrilho (eds.), Manual de Linguística Portuguesa. Berlin/Boston: De Gruyter. 371-400.

\section{Referências}

Aikhenvald, Alexandra (2004), Evidentiality, Oxford/New York, Oxford University Press.

Ambar, Manuela (1992), Para Uma Sintaxe da Inversão Sujeito-Verbo em Português, Lisboa, Colibri.

Ambar, Manuela (1999), Aspects of the Syntax of Focus in Portuguese, in: George Rebuschi/Laurice Tuller (edd.), The Grammar of Focus, Amsterdam/Philadelphia, Benjamins, 23-53.

Ambar, Manuela/Veloso, Rita (2001), On the nature of wh-phrases, word order and wh-in-situ: Evidence from Portuguese, French, Hungarian and Tetum, in: Yves D'Hulst/Johan Rooryck/Jan Schroten (edd.), Romance Languages and Linguistic Theory 1999: Selected papers from «Going Romance» 1999, Leiden, 9-11 December 1999, Amsterdam/Philadelphia, Benjamins, 1-38.

Barbosa, Pilar (2001), On inversion in wh-questions in Romance, in: Aafke Hulk/Jean-Yves Pollock (edd.), Subject Inversion in Romance and the Theory of Universal Grammar. Oxford/New York, Oxford University Press, 20-59.

Barbosa, Pilar (2006), Ainda a questão dos sujeitos pré-verbais em Português Europeu: uma resposta a Costa (2001), D.E.L.T.A. 22:2, 345-402.

Barbosa, Pilar (2009), Two kinds of subject pro, Studia Linguistica 63:1, 2-58.

Barbosa, Pilar/Duarte, Maria Eugenia L./Kato, Mary A. (2005), Null subjects in European and Brazilian Portuguese, Journal of Portuguese Linguistics 4:2, 11-52.

Bianchi, Valentina/Bocci, Giuliano/Cruschina, Silvio (2015), Focus fronting and its implicatures, in: Enoch O. Aboh/Jeannette C. Schaeffer/Petra Sleeman (edd.), Romance Languages and Linguistic Theory 2013: Selected papers from «Going Romance» Amsterdam 2013, Amsterdam/Philadelphia, Benjamins, 1-20.

Cardoso, Adriana (2010) Variation and Change in the Syntax of Relative Clauses, tese de doutoramento, Universidade de Lisboa.

Cinque, Guglielmo (1990), Types of A-Dependencies, Cambridge, MA, MIT Press.

Costa, João (1998), Word Order Variation: A constraint-based approach, The Hague, Holland Academic Graphics.

Costa, João (2004), Subject Positions and the Interfaces: The Case of European Portuguese, Berlin/New York, Mouton de Gruyter.

Costa, João/Figueiredo Silva, Maria Cristina (2006), On the (in)dependence relations between syntax and pragmatics, in: Valéria Molnar/Susanne Winkler (edd.), The Architecture of Focus, Berlin, Mouton de Gruyter, 83-104.

Costa, João/Martins, Ana Maria (2011), On Focus Movement in European Portuguese, Probus 23:2, 217-245.

CRPC - Corpus de Referência do Português Contemporâneo, Lisboa, CLUL, http://alfclul.clul.ul.pt/CQPweb (06.02.2016),

De Haan, Ferdinand (2005), Encoding speaker perspective: evidential, in: Zygmunt Frajzyngier/Adam Hodges/David S. Rood (edd.), Linguistic Diversity and Language Theories, Amsterdam/Philadelphia, Benjamins, 379-397.

Duarte, Inês (1987), A Construção de Topicalização na Gramática do Português, tese de doutoramento, Lisboa, Universidade de Lisboa.

Duarte, Inês (1997), Ordem de palavras: sintaxe e estrutura discursiva, in: Ana Maria Brito et al. (edd.), Sentido que a Vida Faz. Estudos para Óscar Lopes, Porto, Campo das Letras, 581-592.

Duarte, Inês (2003), Frases com tópicos marcados, in: Maria Helena Mira Mateus et al., Gramática da Língua Portuguesa, Lisboa, Caminho, 489-506.

Duarte, Inês (2013), Construções de Topicalização, in: Eduardo B. Paiva Raposo et al. (orgs.), Gramática do Português, vol. 1, Lisboa, Fundação Calouste Gulbenkian, 401-426.

Frota, Sónia/Vigário, Marina (1996), On Weight Effects in European Portuguese, comunicação apresentada no GLOW Workshop on Weight Effects, Atenas. 
Martins, Ana Maria \& João Costa (2016). Ordem dos constituintes frásicos: sujeitos invertidos, objetos antepostos. In: Ana Maria Martins \& Ernestina Carrilho (eds.), Manual de Linguística Portuguesa. Berlin/Boston: De Gruyter. 371-400.

Hernanz, Maria Lluïsa/Brucart, José Maria (1987), La Sintaxis: Principios teóricos. La oración simple, Barcelona, Editorial Crítica.

Kato, Mary A./Martins, Ana Maria (2016), The Main Varieties of Portuguese: an overview on word order, in: Leo Wetzels/Sergio Menuzzi/João Costa (edd.), Handbook of Portuguese Linguistics, Hoboken, NJ, Wiley-Blackwell.

Kuroda, S.-Y. (1972), The Categorical and the Thetic Judgments, Foundations of Language 9, $153-185$.

Kuroda, S.-Y. (1992), Japanese Syntax and Semantics, Dordrecht, Kluwer.

Kuroda, S.-Y. (2005), Focusing on the matter of Topic: a study on «wa» and «ga» in Japanese, Journal of East Asian Linguistics 14, 1-58.

Lambrecht, Knud (1988), Presentational cleft constructions in spoken French, in: John Haiman/Sandra A. Thompson (edd.), Clause Combining in Language and Discourse, Amsterdam/Philadelphia, Benjamins, 135-179.

Lambrecht, Knud (1994), Information Structure and Sentence Form: Topic, focus, and the mental representation of discourse referents, Cambridge, Cambridge University Press.

Lambrecht, Knud (2000), When subjects behave like objects: An analysis of the merging of $S$ and $O$ in Sentence-Focus constructions across languages, Studies in Language 24:3, 611682 .

Larson, Richard (1988), On the Double Object Construction, Linguistic Inquiry 19, 335-391.

Larson, Richard (1990), Double Object Revisited: Reply to Jackendoff, Linguistics Inquiry 21, $586-632$.

Lasnik, Howard/Saito, Mamoru (1992), Move $\alpha$ : Conditions on Its Application and Output, Cambridge, MA, MIT Press.

Leonetti, Manuel (2014), Spanish VSX, in: Karen Lahousse/Stefania Marzo (edd.), Romance Languages and Linguistic Theory 2012: Selected papers from «Going Romance» Leuven 2012, Amsterdam/Philadelphia, Benjamins, 37-64.

Leonetti, Manuel (2015), On word order in Spanish copular sentences, in: Isabel PérezJiménez/Manuel Leonetti/Silvia Gumiel-Molina (edd.), New Perspectives on the Study of «Ser» and «Estar», Amsterdam/Philadelphia, Benjamins, 203-236.

Lobo, Maria/Martins, Ana Maria (no prelo-a), Subjects, in: Elisabeth Stark/Andreas Dufter (edd.), Manual of Romance Morphosyntax and Syntax, Berlin, De Gruyter.

Lobo, Maria/Martins, Ana Maria (no prelo-b), title?, in: Eduardo B. Paiva Raposo et al. (orgs.), Gramática do Português, vol. 3, Lisboa, Fundação Calouste Gulbenkian.

Martins, Ana Maria (1994), Clíticos na História do Português, tese de doutoramento, Lisboa, Faculdade de Letras da Universidade de Lisboa.

Martins, Ana Maria (1997), Alguns, poucos, muitos, todos e a relação Sintaxe-Semântica, in: Ana Maria Brito et al. (edd.), Sentido que a Vida Faz: Estudos para Óscar Lopes, Porto, Campo das Letras, 679-692.

Martins, Ana Maria (2010), Constituent order in simple (and root) declarative clauses, Manuscrito, Universidade de Lisboa, acessível online em: http://alfclul.clul.ul.pt/wochwel/documents/Martins\%20Constituent\%20order.pdf (09.02.2016).

Martins, Ana Maria (2013a), The interplay between VSO and coordination in two types of nondregree exclamatives, Catalan Journal of Linguistics 12, 1-27.

Martins, Ana Maria (2013b), A colocação dos pronomes pessoais átonos, in: Eduardo B. Paiva Raposo et al. (edd.), Gramática do Português, vol. 1, Lisboa, Fundação Calouste Gulbenkian, 2231-2302.

Matras, Yaron/Sasse, Hans-Jürgen (edd.) (1995), Verb-Subject Order and Theticity in European Languages, Berlin, Akademie-Verlag.

Peterson, Tyler/Sauerland, Uli (edd.) (2010), Evidence from Evidentials, The University of British Columbia Working Papers in Linguistics 28.

Raposo, Eduardo (1995), Próclise, ênclise e posição do verbo em português europeu, in: João Camilo dos Santos/Frederick G. Williams (edd.), O Amor das Letras e das Gentes, in 
Martins, Ana Maria \& João Costa (2016). Ordem dos constituintes frásicos: sujeitos invertidos, objetos antepostos. In: Ana Maria Martins \& Ernestina Carrilho (eds.), Manual de Linguística Portuguesa. Berlin/Boston: De Gruyter. 371-400.

honor of Maria de Lourdes Belchior Pontes, Santa Barbara, CA, Center for Portuguese Studies, University of California at Santa Barbara, 455-481.

Raposo, Eduardo (2000), Clitic Positions and Verb Movement, in: João Costa (ed.), Portuguese Syntax. New Comparative Studies, Oxford/New York, Oxford University Press, 266-297.

Rizzi, Luigi (1997), On the fine structure of the left periphery, in: Liliane Haegeman (ed.), Elements of Grammar, Dordrecht, Kluwer, 281-337.

Sasse, Hans-Jürgen (1987), The thetic/categorical distinction revisited, Linguistics 25, 511-580.

Sasse, Hans-Jürgen (1995), «Theticity» and VS order: a case study, in: Yaron Matras/HansJürgen Sasse (edd.), Verb-Subject Order and Theticity in European Languages, Berlin, Akademie-Verlag, 3-31.

Sasse, Hans-Jürgen (1996), Theticity, Arbeitspapier 27 (Neue Folge), Universität zu Köln, Institut für Sprachwissenschaft.

Sasse, Hans-Jürgen (2006), Theticity, in: Giuliano Bernini/Marcia L. Schwartz (edd.), Pragmatic Organization of Discourse in the Languages of Europe, Berlin, Mouton de Gruyter, 257-308.

Torrego, Esther (1984), On Inversion in Spanish and Some of its Effects, Linguistic Inquiry 15, $103-127$.

Zimmermann, Malte (2007), Contrastive Focus, in: Caroline Féry/Gisbert Fanselow/Manfred Krifka (edd.), The Notions of Information Structure, Potsdam, Universitätsverlag Potsdam, 147-159.

Zimmermann, Malte/Onea, Edgar (2011), Focus marking and focus interpretation, Lingua 121:11, 1651-1670.

Zubizarreta, María Luisa (1998), Prosody, Focus, and Word Order, Cambridge, MA, MIT Press.

Zubizarreta, María Luisa (1999), Las funciones informativas: tema y foco, in: Ignacio Bosque/Violeta Demonte (edd.), Gramática Descriptiva de la Lengua Española, vol. 3, Madrid, Espasa-Calpe, 4215-3244. 